\title{
The Failure of Peace Processes: The Specific Case of the Central African Republic
}

\author{
Mario Azou-Passonda*, Wei Hong, Zéphirin Mobogaina, Ghislain Gervil Kossingou, \\ Serge Kevin Gildas Soule Baoro \\ Central China Normal University, Wuhan, China \\ Email: *james.mario@live.fr
}

How to cite this paper: Azou-Passonda, M., Hong, W., Mobogaina, Z., Kossingou, G. G., \& Baoro, S. K. G. S. (2019). The Failure of Peace Processes: The Specific Case of the Central African Republic. Open Journal of Political Science, 9, 472-489. https://doi.org/10.4236/ojps.2019.93026

Received: May 6, 2019

Accepted: May 31, 2019

Published: June 3, 2019

Copyright $\odot 2019$ by author(s) and Scientific Research Publishing Inc. This work is licensed under the Creative Commons Attribution International License (CC BY 4.0).

http://creativecommons.org/licenses/by/4.0/

\section{(c) (i) Open Access}

\begin{abstract}
The peace process, resulting from a peace agreement, is a series of actions whose achievement aims to provide a definitive solution to an armed conflict. This process is established over a long period of time, hence the importance of support from UN agencies. The lack of implementation of the actions advocated in this process can plunge the country into crisis. This crisis can intensify and lead to a chaotic situation, as in the case of the Central African Republic (CAR). We analyze the failure of 13 peace agreements signed in the context of the conflict in CAR between 1997 and February 2019. We see that the lack of reasonable sharing of power with the opposition (political and military) in these peace processes is a determining factor in the failure of this process. The reluctance to share power is motivated by the sharing of the cake between clans and parliamentary coalition acquired for the benefit of regimes. Also, the regimes have little interest, purposely for institutional reforms, the final disengagement of armed militias and the establishment of justice to prosecute the perpetrators of human rights violations and international crimes. This study has an implication for CAR seen around the world as the champion of peace processes and peacekeeping missions.
\end{abstract}

\section{Keywords}

Peace Process, Agreements, Failure, Sharing Power, Central African Republic

\section{Introduction}

In all internal conflicts, the peace talks are aimed at restoring peace in a peace process over a long period of time. The non-consensual management of this 
process is a threat to peace, beneficial to the regimes in place, but damaging to the civilian population. This article examines the characteristic elements of the failure of the management of the peace process in the crisis in the Central African Republic. We consider the failure of peace processes as the failure to implement the actions that follow the signing of agreements aimed at finding a lasting solution to armed conflict in CAR. The peace process is a series of steps that can span several years to prevent conflict from re-emerging. The strengthening of the presence of United Nations agencies in recent years aims to accompany this process over time.

By scrutinizing the various peace agreements signed without real effects in the Central African crisis between 1997 and 2013, we highlight the bad governance to explain the recurring failure of peace processes in CAR. The peace process should allow the final cessation of hostilities against civilian populations and the disengagement of armed groups. At the same time, the peace process should pave the way for transparent management of power. This type of management requires a fair sharing of power and the implementation of institutional reforms. Like that, the political and armed opposition as well as the populations acquired to their cause could have confidence in the republican institutions. However, the management of the state's funds in countries rich in natural resource allow better to understand the reason for the recurring failure of the peace agreements. Also, it allows knowing the reluctance of the political opposition to support a regime that leads a patrimonial management of public affairs. Fernandez-Fernandez et al. (2014) links the definition of the term natural resources to the satisfaction of the objectives of maintaining systems supporting life on Earth and basic human needs. In CAR, natural resources have a negative impact. The explicit conclusion was described by Karl (1997). According to Terry Lynn Karl, the exploitation of the wealth of the subsoil tends to weaken the economic fabric, the social cohesion and the political institutions of the producing countries. Despite the exploitation of natural resources (gold, diamonds, etc.), the people of CAR are still in misery due to poor governance. Institutional reforms are an integral part of the peace process with the aim of creating the conditions for consensual management. This consensual management leads to good governance that aims to legitimize government action and make it more effective for the benefit of the general interest. Our data cover all the peace processes initiated under the peace agreements signed between 1997 and February 2019 in CAR. We are conducting a prospective study with quantitative data to test hypotheses about the failure of peace processes in CAR.

\section{Theoretical Framework}

How do the regimes manage to defeat the peace process? What are the strategies that regimes are putting in place to defeat the peace process? The theoretical framework of this study aims to analyze the recurrent failure of peace processes in neo-patrimonial regimes. Our theory highlights the elements that cause the 
failure of peace processes following the signing of peace agreements. We theoretically believe that when peace agreements are signed, the regimes will engage in unilateral management of the peace process, putting the peace process in trouble. First, we assume that in peace processes, regimes are supported by clans and parliamentary majority that benefits from predatory management. Second, we assume that when the regimes have a parliamentary majority, they are very easily disengaged from the peace process. They begin by avoiding the realization of the sharing of power advocated by the peace agreements that they themselves signed. Third, we assume that these regimes have little interest in institutional reform. These institutional reforms are supposed to give rise to a balanced and transparent management of public affairs. Also, we assume that these regimes do not enshrine the DDR process which aims to pacify the country. Institutional reforms and DDR are generally seen as the counterpart to the disengagement of armed groups' elements (Specht et al., 2010). The recurrence of peace agreements in CAR may also be related to the mismanagement of these accompanying measures. Finally, we believe that most regimes have voluntarily avoided the implementation of substantial justice to prosecute those who have committed international crimes. The perpetrators of crimes, whatever their social status, should be punished conforming to the law.

Peace agreements are a step in the peace process, which indeed is a very long process. We regard a peace agreement as an agreement of wills ending a war between belligerents who agree to make reciprocal concessions. The crisis in CAR has seen several negotiations leading to the signing of several peace agreements from 1997. This study is of decisive importance. Our assumptions are tested on the peace processes involved in the Central African crisis from 1997 to 2019. The CAR is a country at the heart of a chronic instability that has only experienced coups since independence. She is considered like the champion of agreements and peace missions. The different peace processes in this crisis constitute a sample that can be studied quantitatively. The predictions of our assumptions concern the elements that make the failure of a peace process predictable.

\section{Materials}

Our analysis focuses on the implementation of the peace agreements that engaged the Government and the rebels around a negotiating table. We exclude the peace agreements of Kenya (2014) and Angola (2016) to which the Central African Government had not taken part. These agreements were a reconciliation agreement between the former Seleka and Anti-Balaka groups. This agreement initiated a new period of political transition and the return of the two former presidents supporting these two rival rebel groups in political affairs in CAR. Both agreements were rejected by the Central African Government and the International Community immediately after their signature announcement (Vincent Duhem, 2015; Thierry Vircoulon, 2017). 


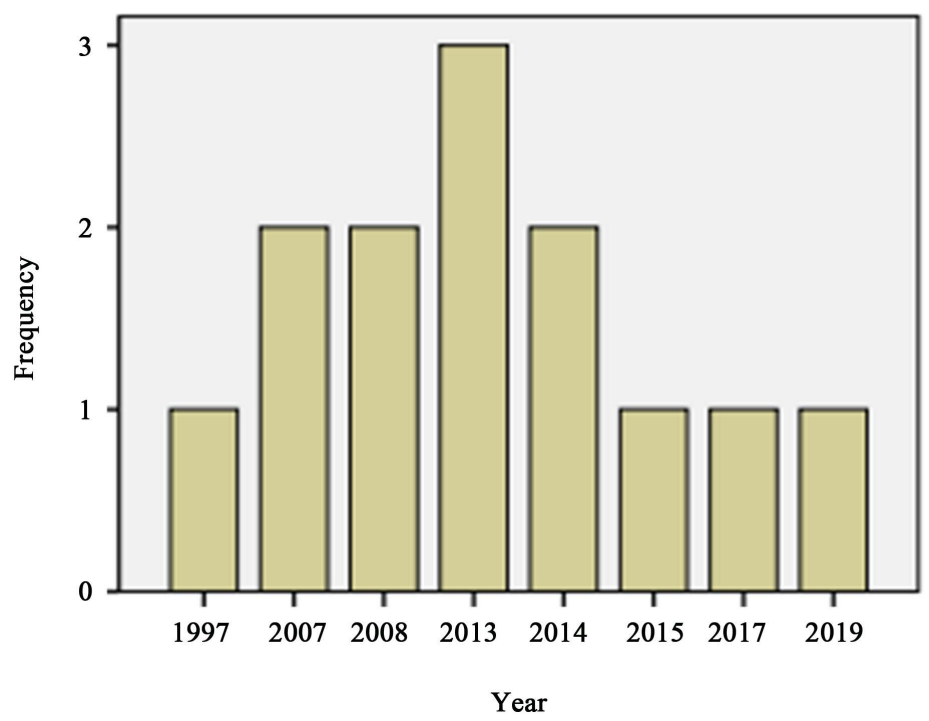

Figure 1. Agreements frequency. $\mathrm{N}=13 ; \mathrm{Min}=1 ; \mathrm{Max}=13 ; \mathrm{M}=7,00 ; \mathrm{SD}=3894 ; \mathrm{V}=$ 15,167 .

Figure 1 indicates that 13 peace agreements were signed ranging from the Bangui Agreements from 1997 to 2019, including three agreements in 2013. Here, we present a brief overview of these peace agreements signed between the outbreak of the crisis in 1996 and its persistence in February 2019.

\subsection{The Bangui Agreements of 1997}

The Bangui agreements were concluded in 1997. In fact, the CAR was plunged into a political and economic crisis in 1996. Three mutinies erupted successively between 1996 and 1997. In April, many soldiers went into rebellion to demand payment of their salaries and an improvement in their living conditions. A month later, a second mutiny broke out. They demanded the implementation of the commitments resulting from the April mutiny. The regime of the President Ange-Félix Patassé was seriously threatened (United Nations, 1997). France implemented "Almandin 2" Operation to protect institutions, as part of defense agreements with the CAR and to guarantee the safety of its nationals (ECPAD, 2010). In November, the third mutiny broke out and the social crisis turned into a political and clan crisis, involving opposition political parties (Oscar, 2001). At Patassé's request, a truce was negotiated on behalf of the 19th Summit of Heads of State and Government of France and Africa. Some African Presidents were mandated to lead negotiations. The military operation called the Inter-African Mission to Monitor the Implementation of the Bangui Agreements (MISAB in the French initial) was created (United Nations, 1997). The Bangui agreements advocated respect for constitutional legality, the formation of a genuine government of national union extended to all political parties and to the civil society, amnesty, strict application of legal and regulatory texts, and consensual acts, etc. In 2001, an attempted coup led to the creation of a rebellion that culminated in the coup d'état of 2003. 


\subsection{The Sirte and Birao Agreements of 2007, and the Libreville Agreements of 2008}

Two agreements were signed in 2007 and two others in 2008. The first three agreements were signed with the armed groups separately. The Sirte (Libya) agreement was signed on February 2, 2007, between the Central African Government and the armed opposition represented by AbdoulayeMiskine of the Democratic Front of the Central African People (FDPC from the French initials). All rebel groups were supposed to adhere to this agreement. But, the Union of Democratic Forces for Rally (UFDR) rejected the agreement. A specific agreement was signed in Birao (CAR) in 2007. The Libreville (Gabon) agreement of May 2008 was signed with the Popular Army for the Restoration of Democracy (APRD). These agreements provided, among other things, the power sharing, amnesty and rehabilitation of rebel fighters. These agreements were violated immediately. In June 2008, the Libreville Global Peace Agreement was signed to compensate for the failure of these previous agreements.

\subsection{The Libreville and N'Djamena Agreements and the Republican Pact of 2013}

The Libreville agreement was signed in 2013. In fact, the various rebel movements merged to form the "Séléka" coalition in 2012. The Seleka took control of several cities in the country, from the north to the gate of the capital. Acts of torture, heinous crimes, rape and looting have been reported in their wake. In order to stop the hemorrhage, the international community through the Economic Community of Central African States (ECCAS) mobilized for a final agreement to end the crisis (Lombard, 2012). But, two months after the signing of the Libreville agreement, hostilities restarted. The N'Djamena Agreement 1, known as "Declaration of N'Djamena" was signed on April 18, 2013, after the coup against Bozizé in March. At this time the Seleka was in power. The N'Djamena agreements 2 were signed on January 10, 2014. These agreements were signed by the Seleka under the constraint of the Heads of State of the ECCAS, as aimed to the removal of the self-proclaimed President Michel Djotodja (Mayneri, 2014). The Republican Pact was signed in Bangui on November 7, 2013. This pact aimed to establish power sharing and the establishment of a constructive dialogue ${ }^{1}$.

\subsection{The Brazzaville Forum of 2014}

The Brazzaville Forum (Congo) for peace in CAR was initiated by the Contact Group for Peace in CAR in 2014. After bitter negotiations, the Brazzaville Forum resulted in a ceasefire agreement. This forum continued in Bangui in 2015 under the name of Bangui Forum. The aim was to finalize the Brazzaville Forum through a process of political dialogue and national reconciliation. But, the last day of the works, the rebels not satisfied, denounced the Brazzaville agreement. ${ }^{1}$ http://www.justiceinfo.net/media/k2/attachments/RCA/VF-Centrafrique-tableauaccords.pdf. 


\subsection{The Rome Agreements of 2017 and the Bangui Agreements of 2019}

The Rome peace talks resulted in "Entente of Sant'Egidio" in June 2017. This agreement provided for a general amnesty for armed groups. However, the Rome agreements were also rejected in violence. In 2019, the African Union sponsored the Khartoum (Sudan) peace talks between the government and the 14 armed groups. The peace agreement was signed in Bangui on February 6, 2019. In March, the appointment of the new government provoked the disapproval of all armed groups and political parties of the opposition. Armed groups threatened to carry on hostilities.

All these agreements provided inter alia, the immediate cessation of hostilities, the renunciation of rebels to the armed struggle and the power sharing. These agreements, which are the foundations of the implementation of the peace process, have not been respected.

\section{Methodological Framework}

The sampling technique on the failure of peace agreements is developed on the basis of agreements that have resulted in power sharing and extended to other variables. We collected data on the peace process from the signing of the peace agreements from 1997 to February 2019. Over this period, 13 agreements were signed, an average of 7.00. These agreements have given birth to the effective implementation of the peace process. We have separately identified the agreements that led to power sharing and those that did not result in power sharing. Secondly, we have defined the relations of parliament with the regimes in each peace process. End for each peace process, we have identified accompanying measures to consolidate peace, including institutional reforms and DDR. For example, in the case of power sharing, four agreements led to power sharing. These are the Bangui agreements of 1997 and the three agreements signed in 2013. We performed the same procedure for all other variables. For the specific case of Not Power Sharing, we found a difference of $7.7 \%$ with the Power Sharing rate. We conducted the analysis of these data in using the Ordinary Least Squares (OLS) method. This analysis aims at two discriminating results states (the failure of the peace process and the success of the peace process) and the discrete categories of a series of predictor variables. Since each peace process represents a specific peace agreement, we view it as an independent observation whose failure must be expressed as a continuous variable. The failure of the peace process is the main outcome variable. The failure of the peace process would take the value 1 if an agreement was denounced or a power was not shared, and 0 if the agreement was respected or the power was shared.

Our research hypotheses are as follows:

Hypothesis 1: The failure of the peace process should be obvious if the regimes do not respect the political terms contained in the peace agreements.

Hypothesis 2: The failure of the peace process should be significant when the 
regimes have a coalition.

Hypothesis 3: As the accompanying measures of the peace process are not realized, the failure of the peace process will become inevitable.

Regarding hypothesis 1, we compare the rate of power sharing with that of the non-sharing of power over all peace agreements signed. We are looking apart the $7.7 \%$ of co-optation, which usually does not contribute to the success of the peace process. We consider that the low rate of power sharing is a measure that contributes significantly to the failure of the peace process.

Regarding Hypothesis 2, we check the position of the majority coalition in parliament at the time of the conclusion of peace agreements. This measure allows us to determine the parliamentary majority and the generally clannish support that leaders can take to achieve non-consensual management of peace processes.

For Hypothesis 3, we use three accompaniment measures: institutional reforms, DDR and justice. We seek to know the determination of the plans and the related achievements.

Since the sample is analyzed in a discriminating manner, the observations are classified into two mutually exclusive groups according to the binary categories method.

\section{Results}

Figure 2 reflects the implementation characteristics of the peace process in CAR since 1997. The sharing of ministerial portfolios is $30.8 \%$ of the agreements, the Bangui agreements of 1997 and all of 2013 specifically. 61.5\% of the agreements did not result in power sharing. $61.5 \%$ of agreements are signed under regimes with a parliamentary majority. It was the Bangui agreements of 1997, the all agreements of 2007 and 2008, the Ndjamena agreements 2, the Rome agreement of 2017 and the Bangui Agreement of 2019. 23.1\% of the agreements resulted to the partial institutional reforms. It was the Bangui agreements of 1997,

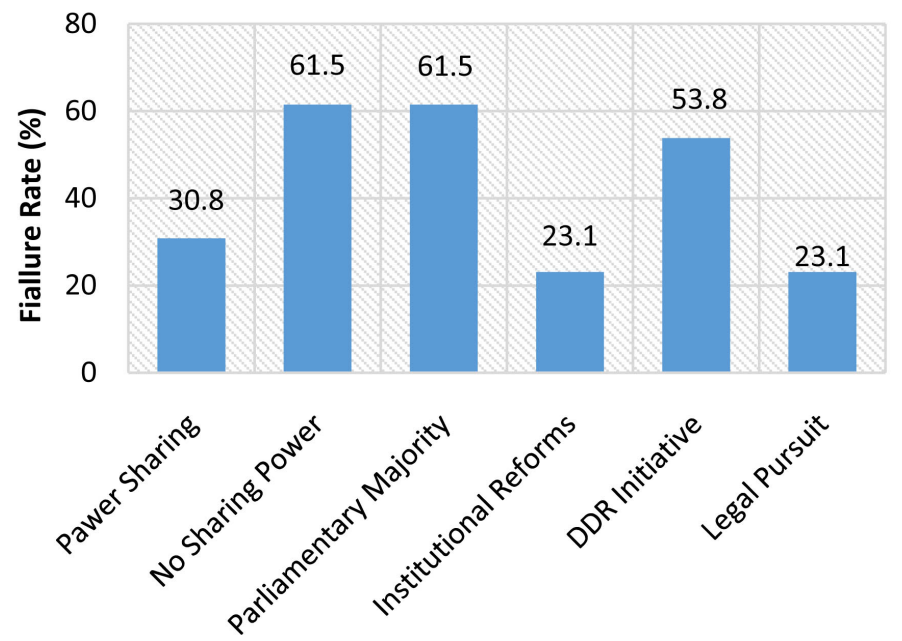

Figure 2. Descriptive rates of specific factors of the failure of the peace process in CAR. 
the N'Djamena agreements of 2013 and the Rome agreement of 2017. 53.8\% of the agreements had a DDR initiative. We found that the Bangui agreements of 1997 succeeded the DDR process. Also, there was some DDR initiative under the Brazzaville agreements of 2014, the Bangui forum of 2015 (from the Brazzaville agreements of 2014), the Rome agreement of 2017 and the Bangui agreement of 2019. $23 \%$ of the agreements resulted in criminal prosecution. It was only the Bangui agreements of 2015 and 2019.

\subsection{The Case of Co-Optation}

We consider the non-sharing of power as a separate variable. This allow as to be sure in the reality of the management of the peace process. Being quantitative, the sharing of power and the non-sharing of power make $92.3 \%$ of all agreements. If this percentage should be taken from the percentage of power sharing, we cannot discover the difference of $7.7 \%$. This difference could be a case of co-optations. There is a rather imprecise literature on the case of co-optations. This literature data does not cover all the agreements nor fill the difference of the percentages existing between these two variables. By deduction we conclude that the remaining $7.7 \%$ corresponds to the case of co-optations. We find that in most cases there is no cabinet reshuffle, but opposition members are appointed as Councilors to the Presidency and the Prime Minister cabinets. Also, we find that regimes can issue appointment decrees that have no effect on the principle of power sharing. This situation is explained by the protest of the opposition members for lack of consensus around the distribution of posts (RFI, 2019). Likewise, the succession of peace agreements demonstrates that even the sharing of power is not satisfactory in their application. This explains the existence of a radicalization of the regime, leading the opposition representatives to resign. There is a common practice in CAR that regimes appoint Deputy Ministers or Cabinet Directors alongside Ministers holding opposition positions (France 24, 2013). These delegated ministers or heads of cabinets systematically constrain the decisions of the regular ministers, which makes cohabitation unbearable. Generally, the opposition ministers end up resigning, giving free rein to the regimes. In CAR, co-optation has a double benefit in both directions. On the one hand, they constitute a strategy for the regimes to implement their policies without really taking into account the political demands of the opposition. As a result, it aims to socialize opposition to the visions of the regimes. Also, it allows them to monitor the actions of the opposition as in the case of Burkina Faso (Loada, 2010). With regard to some co-opted persons, cooptation is a way for them to gain a privileged place in society. Also, Marchal (2015) believes that in the CAR co-optation is a privileged hope for co-opted persons to find a place in the political life arenas.

Co-optations are an alternative strategy that regimes have to soften the opposition and tie them to the plans. But this strategy has only a short term. It is also a source of failure of the peace process. The multiplication of peace processes in CAR proves that the regimes prefer to assign the responsibility positions on a 
subjective basis. This strategy contributes significantly to the failure of the peace process. Co-optations is considered as coming from a single will, without any consensus spirit. This desire cannot be assimilated to an accordant situation. The co-optations are explained by the fact that after signing peace agreements, the regimes choose moderate representatives of the political opposition or armed groups to integrate the government. Often, this strategy product a small effect, but not for long time. Co-optation creates opportunities for duplication between the plans and the people targeted by cooptation. The level of poverty is such that it is easy for these people to take advantage of this situation to benefit from it (Marchal, 2016).

\subsection{The Non-Equitable Sharing of Power, a Main Factor of Non-Consensual Management}

Table 1 shows the characteristics of the failure of the peace process in CAR. In column 1, we use predictors to test the three hypotheses. These predictors are specific to each variable. The results significantly confirm each of our hypotheses. The non-respect of the political terms contained in the peace agreements leads directly to the failure of the peace process. The adjusted $\mathrm{R}^{2}$ is in brackets, indicating the rate of probability of failure of the peace process based on each variance. Like so, in the Figure 2, power sharing is carried out at a rate of $30.8 \%$ (Figure 2). The power sharing predicts the probability of the failure of the peace process to the tune of $35.4 \%$. The no sharing of power with $61.5 \%$ predicts this failure of the peace process to the tune of $49.4 \%$. In column 2 , we use sharing power as predictor. The result concludes with a significant failure due to the unequal sharing of power. The power sharing significantly predicts the no sharing of power. The power sharing is $30.8 \%$ and the no sharing power is $61.5 \%$ (Figure 2). This corresponds in column 2 to $68.5 \%$ of the part of variance of the no sharing of power explained by the sharing of power. Power sharing is, therefore, a relevant variable to explain the no sharing of power; therefore not attributable to chance. This means that the power sharing predicts $68.5 \%$ probability of no sharing power in the midst of the peace process. The parliamentary majority is estimated at $61.5 \%$ (Figure 2). It predicts the probability of the peace process failure at $68.5 \%$. These results indicate that the existence of a presidential

Table 1. Specific characteristics of the failure of peace processes. (Dependent variable: Failure).

\begin{tabular}{ccc}
\hline Variables & 1 & 2 \\
\hline Power Sharing & $0.019(0.354)$ & $0.001(0.685)$ \\
No sharing Power & $0.004(0.494)$ & \\
Parliamentary Basis & $0.001(0.685)$ & \\
Institutional Reforms & $0.043(0.259)$ & \\
DDR & $0.004(0.494)$ & \\
Legal Pursuit & $0.002(0.570)$ &
\end{tabular}


majority in parliament is a major risk to the success of the peace process. These results also indicate that the no sharing of power would be the consequence of the existence of a parliamentary majority in favor of the executive power. Institutional reforms and Disarmament Demobilization Reintegration (DDR) are carried out in part $23.1 \%$ and $53.8 \%$ (Figure 2). These two variables predict the failure of the peace process by $25.9 \%$ and $49.4 \%$, respectively. Justice was not taken into account in peace processes, only $23.1 \%$ (Figure 2). It predicts the failure of the peace process by $57 \%$.

The political terms contained in the peace agreements are mainly related to the power sharing that is the condition of a transparent or a democratic management of power. Power sharing involves appointing people from the opposition to senior positions of responsibility (ministerial departments). After peace negotiations leading to power-sharing, the regimes don't respect the political terms contained in these agreements. The reasons can be of two kinds. First, non-consensual management derives its essence from a social framework favorable to the regimes in place. This framework may be the ethnic group of the ruling president or the ethnic groups that have affiliated with his cause that we call clans. In this way, the regimes are established by clans from different horizons. These clans are a major support for the stability of the regime in CAR. They are generally interested in ministerial positions or other prerogative positions of ministers in return for their support. When they come to power, these regimes consider it an obligation to reward them with ministerial positions. This means that even when the plans are mid-term, these same people stay in their positions. Failing that, they continue to gravitate around power with high-level accreditation (International Crisis Group, 2007). Added to this is complete immunity for crimes (especially financial crimes). Peace agreements that result in power sharing pose a threat to them. When power sharing is to be done, they are appointed as deputy ministers or cabinet ministers to monitor the actions of the ministers from opposition. As we said, this type of cohabitation always ends up bursting. We also found that the regimes have found a strategy to avoid the disengagement of their coalition members. Thus, they appoint opposition members as ministerial advisers at the Presidency or Prime Minister cabinets. This solution also has no impact on the peace process. This was the case in 2011 when President François Bozizé appointed six leaders of the armed group as presidential advisers on DDR. But no confirmation of their inauguration had been announced (Amnesty International, 2011). Sometimes they can take office as advisors, but the result remains the same. This is the case with the peace process stemming from the Rome Agreement of 2017.

Second, non-consensual management can come from a policy framework. This framework is constituted either by the political party of the president, or by the presidential majority in the Parliament. This association also largely benefits the deputies of the nation which exercises their function without any control measure nor respect for the deontology. In CAR, it is generally recognized that after the elections many members of parliament do not go to their constituency. 
They are most often in Bangui or out of the country as part of their personal business (Moloma, 2018). The importance of political support is a major asset for the regimes to establish non-consensual management of the peace process. In Africa, the president is both head of state and party leader. Babacar Guèye (2009) estimates that as head of his party, only the president can draw up the list the candidates of the party to the polls. By consequence, he is the leader of the majority coalition in the Parliament. It results from this accumulation a concentration of executive and legislative powers in his hands. The executive and the parliament are no longer separated, but in solidarity under the authority of the president, who holds the majority. The recent literature has shown that in CAR between 1993 and 2003, a parliamentary majority ruled by MLPC (Liberation Movement of the Central African People) was acquired in parliament in favor of the executive. Similarly, between 2005 and 2013, a majority governed by the KNK party (Kwa Na Kwa, meaning "work, nothing but work") was also acquired for the benefit of the executive. For the latter case, the literature has shown that during the parliamentary elections, the party of Bozizé won a solid majority. Twenty members of the new parliament from the KNK party have a direct family link with the president. Still others have presented themselves as independents, making the president's control even wider over parliament (Lombard, 2012; United Nations, 2017). We believe that this strategy prevents the real exercise of parliamentary control on the Government action. Parliamentary control is a set of procedures available to parliamentarians to monitor government activity (Yamamoto, 2007). There would be more reliability if the parliamentary control is exercised by the opposition acting in the interest of the people. This could contribute to the democratization of institutions.

The peace process is a long enough periods that could take many years, even decades. We believe that the recurrence of the Central African crisis since 1997 reflects the lack of accordant management of CAR's post-conflict situation. The different plans have relied on the qualifier of "democratically elected" defended by the regimes to justify the non-consensual management of power. The "democratically elected" qualifier is only one of two necessary conditions for undeniable legitimacy, the other being the "good" exercise of power won at the polls (International Crisis Group, 2007). The proper exercise of power involves, among other things, the democratic exercise of power and financial transparen$\mathrm{cy}$, respect for human rights, and so on. Likewise, the non-consensual management has led to the mismanagement of public affairs during all periods of peace processes. We believe that the acquisition of a majority in parliament for the benefice of the president is a perversion of democracy. It's a significant breach to the principle of the separation of powers. Democracy advocates the principle of the separation of powers, the opposite would be a dictatorship.

This mismanagement system is very widespread in Africa. The regimes in Africa base the peculiarity of their reign on their legitimacy which they use as a means of discarding political dialogue. According to Mambo (2012), the executive power in Africa bases its legitimacy on the constitution that it instrumenta- 
lizes for its benefit. However, this constitution is the cause of a faintness of African political societies. That is why political arrangements (peace process) are needed to overcome the inadequacies and shortcomings of the constitution. Although the will of the people is at the root of this legitimacy, however, this legitimacy could be lost for lack of accordant management (International Crisis Group, 2007). The fact that a regime in a peace process relies on the legitimacy of its power to override the consensual management of the peace process leads to the stalemate of the situation. This was the case of Ivory Coast from 1999. The crisis has resulted from the gearing of several factors. The economic depression has accentuated the social and political crisis. This one has negative feedback on the economy. Eventually the conflict became military with control of the north by the forces of the Patriotic Movement of Ivory Coast (Philippe, 2003). Moreover, a parliamentary majority does not necessarily mean popular legitimacy. For example, between 1997 and 2003, and between 2016 and 2019, the regimes enjoyed a parliamentary majority. However, their legitimacy was very unstable. The parliamentary majority is won by political and interested negotiations. While legitimacy is the consequence of a national policy in the sense of the expectation of the people.

The second reason for the regimes to be reticent in the sharing of power could come from coups. Most regimes between 1997 and 2019 suffered coup attempts or armed uprisings. Two of them were overthrown by a coup. All these events led to a crisis of confidence during peace processes. Since 2003, rebel groups without exception have been guilty of international crimes (United Nations, 2017; The Sentry, 2018). But this should not justify going to negotiate a peace agreement and then failing to live up to the commitments that come with it. But the schemes are guided by a new form of patrimonial appropriation of public goods. We see, in particular, an extreme personification of power, a real patronage system and mismanagement of state resources (Yves-André and JeanFrançois, 1995). The regimes are used to misappropriating the natural resources of the country. This was the case with the granting of forestry and mining permits. For example, the company La Colombe Forests of the President under the peace process of 1997 held a 400,000 hectare license. La Colombe Mines was responsible for the mining exploitation. Furthermore, this president was present in the distribution of petroleum products through Transoil Company (Oscar, 2001). In analyzing the crisis in the Central African Republic, Doui Wawaye (2012) felt that the deterioration of the situation in CAR results in an obvious erosion of professional morality. Corruption, indiscipline, trafficking in influence and immunity. These practices tarnish the image of the institution among the populations. The regimes consider power sharing as an obstacle. The response to this type of predation is reflected in mutinies and coups that bring the peace process back to its original state. According to analysts of Central African political life, appointments to ministerial positions without consensus spirit provoke protests from armed groups and even opposition political parties (Ngoulou, 2019). 


\subsection{The Lack of Institutional Reforms and DDR}

If the accompanying measures of the peace process are not realized, the failure of the peace process will become inevitable. Institutional reforms and DDR are a very important asset for the stability of a country in a transitional (post-conflict) period. The success of a peace process is also conditioned by their achievement. In the Central African case, we found that institutional reforms are far from being achieved. Institutional reforms also involve security sector reform. For the security sector, we found that reform only started recently. This makes the balance sheet very mixed (International Crisis Group, 2007). The institutional reforms are the phase of democratization of state institutions. In the area of transitional justice, institutional reforms are seen as a guarantee of non-repetition. They aim to reform the structures and institutions of the state that facilitated or encouraged the outbreak of hostilities. They aim to effectively address the root causes of conflict and related repressions. The United Nations considers institutional reform to be a forward-looking one as it serves the interests of society as a whole (United Nations, 2014). Institutional reforms make it possible to involve all citizens in order to achieve the success of the peace process. It enables the political representativeness of society in all its diversity. Thus, the new institutions resulting from these reforms represent a guarantee allowing the participation of the whole population in the reconstruction and the development of the country.

DDR is the security phase of the peace process. It is the ultimate phase of the disarmament of irregular forces. DDR release these fighters from their groups and helping them reintegrate into civil society (United Nations, 2019). It is preceded by a cease-fire agreement. We have noted that on several occasions' cease-fire agreements has been signed by the opposing forces. This has resulted in the more or less temporary cessation of hostilities in order to allow the negotiations to continue. We found that often the cessation of hostilities led to the resumption of hostilities. The main reason is that the funding provided by the international community was simply diverted by the regimes (Chauvin, 2018). This ties in with the question of the predation of state resources in neo-patrimonial regimes mentioned above. Yet institutional reforms and DDR are widely recognized as key elements in the post-conflict peacebuilding process (Bryden, 2007). As Reuter and Szakonyi (2019) have pointed out, institutional constraints on dictators are often weak and undermine their ability to make credible commitments to power-sharing.

The goal of the peace process is to complete institutional reforms and DDR operations. The failure of institutional reforms and the DDR operations is leading to the resurgence of hostilities. Many thinkers link the current chaotic situation in CAR with the failure of DDR operations. Since 2007, the international community has supported several DDR operations that have not been successful. The armed groups prospered and managed to make the CAR ungovernable (Gerold and Merino, 2014). Other thinkers believe that the deterioration of the CAR would also be linked to the broken promises of commitment to institutional reforms (International Crisis Group, 2007). It also proved that the DDR oper- 
ations that followed the crisis of 1996 and 1997 were a success. In 1999, following the presidential election won by Ange-Félix Patassé, the United Nations considered that their mission was accomplished. The United Nations Mission in the Central African Republic (MINURCA in its French initial) peacekeepers were withdrawn in April 2000. In May 2001, a fresh coup attempt again plunged the CAR into psychosis. This coup attempt created the rebellion of Bozizé who took power by force in 2003. We think that the UN agencies should help the CAR to realize the present peace process, whatever the time it should take.

The absence of reforms remains the main cause of this situation. All the agreements mentioned above were signed following hostilities between government forces and armed groups. Each of these agreements provided for the complete disarmament of armed groups and their demobilization and reintegration into appropriate activities on a case-by-case basis. Added to this is the use of a form of amnesty conditional on DDR. Three amnesty laws were passed in 1996, 2003 and 2008 (International Crisis Group, 2017). This would imply that institutional reforms should be conducted in the same way as DDR operations.

\subsection{The Inconsideration of Justice}

In analyzing the framework of justice in the implementation of peace processes, we found that justice has not been seriously considered. Since 1997 to 2017, the agreements have given rise to immunity, even for those guilty of international crimes. After an amnesty law in 1996, the agreements in Bangui advocated the abandonment of criminal prosecution. Thus, a new amnesty law was passed in 1997. This practice introduced a culture of immunity that continued throughout the various peace processes later. In 2004, all prisoners guilty of minor offenses were amnestied (UNHCR, 2005). The peace processes of 2007, 2008 and even 2017 called for an amnesty law. In 2007 and 2008, amnesty laws were passed (FIDH, 2008). From 2013, pressure from the international community, opposition, political parties and civil-society organizations prevented new amnesty laws. We consider that these amnesty laws did not only concern the rebels. The regimes also are guilty of crimes through the forces that are under their orders (United Nations, 2017). As a result, these amnesty laws were also a means of amnesty.

The absence of justice in a peace process impedes accountability, but encourages mistrust. Justice in a peace process aims to address the injustices that occurred during hostilities. According to the Secretary-General of the United Nations, "The transitional justice is a full range of processes and mechanisms associated with a society of attempts to ensure accountability, serve justice and achieve reconciliation" (United Nations, 2004). The importance of justice lies in identifying and prosecuting perpetrators of international crimes. This is also a guarantee for the repair and prevention of conflict, a deterrent (United Nations, 2014).

Justice also involves the compensation of the inequalities that are at the root of the discontent that led to the breakdown of peace. Throughout the peace 
process, victims have not accessed any form of compensation. No measures to improve the lives of the victims and/or their families have been considered. According to the United Nations (2017), many people have been victims of extrajudicial executions, sexual and gender based violence in CAR. Other people have been maimed, tortured, severely abused, etc. Thousands of minor children were recruited and hired as soldiers. Public and civilian property was looted, houses burned. According to UNHCR statistics at the end of December 2017, 688,700 Central Africans were displaced across the country, an increase of $60 \%$ over the end of 2016. At the same time, the number of Central African Republic in neighboring countries reached 542,380 , an increase of $12 \%$ compared to the end of 2016. The CAR has about 4.6 million inhabitants. As a result, these statistics bear witness to an appalling level of suffering (UNHCR, 2018). To date, a common memory has not yet been erected. The reconciliation that results in coexistence and reliving together require the development and appropriation of a common memory in this sense. This also involves the erection of memorials (American Friends Service Committee, 2011). The duty of memory is generally considered as a useful precaution to guard against the later development of revisionist theses. It preserves the collective memory of oblivion (Mottet \& Pout, 2011). Also, reparations involve symbolic actions such as a public apology from those who are not guilty of international crimes. This is an alternative to criminal prosecution.

\section{Conclusion}

We have described the typical conditions that have led to the failure of peace processes in CAR. The variables are developed on the basis of 13 peace agreements signed from 1997 to February 2019. We developed a theme on neo-patrimonial governance to explain the failure of peace processes in CAR. Our measures indicate that the fair sharing of power following a peace agreement will result in the failure of the peace process. The contribution of the opposition (political and military) to the success of the peace process lies in the transparency management.

The failure of peace processes is at the center of non-consensual management by the regimes. Clans and a parliamentary majority intertwine to form these regimes through a majority in parliament for the benefit of those in power. The acquisition of a parliamentary majority is one of the fundamental reasons for the failure of the process in a neo-patrimonial country like the CAR. The regimes generally rely on this form of legitimacy to advocate the no equitable sharing of power, despite the signing of a peace agreement calling for power-sharing. In CAR, as in many African countries, the head of state is both head of his political party. To get a presidential majority means to become the leader of this majority. This amounts to having undeniable control over the parliament. This is a significant departure from the principle of the separation of powers and a perversion of democracy. Almost everywhere in Africa, institutions are in crisis. The organ deliberative and the governmental body are confused in the hands of one person. 
This crisis eventually undermined the legitimacy of the institutions involved, increased instability and undermined the morale and foundations of the nation (Yacine, 1983).

The failure of the peace process is also linked to the lack of institutional reforms and the disarmament, demobilization and reintegration (DDR) process. The institutional reforms aim to strengthen and democratize public institutions in order to prevent hostilities from resurging. Institutional reforms also involve security sector reform. The reform of this sector takes into account the DDR which aims to achieve the final disengagement of the members of the armed groups. Security sector reforms have only recently begun and considerable efforts remain to be made. The implementation of justice is also a crucial point in the failure of peace processes in CAR. Since 1997, the regimes have avoided putting justice at the center of post-conflict concerns. Their motivation is conditioned by the fact that most of these schemes were responsible for the groups, at some point in the crisis. These armed groups have been accused of mass violations of human rights, including international crimes. By granting amnesty to the members of the armed groups they are fighting, they are amnesty themselves.

Through this description, we develop a prediction that can be realized if all these conditions are met. Our study is limited by the fact that it cannot predict the failure of the current peace process from the Bangui Agreement of 2019 revised by the Addis-Ababa agreement of March 20, 2019. Thus, our study cannot predict the exact date of the failure of this ongoing peace process. But it only gives clues the existence of which will lead to the failure of the peace process. The implication of this study lies in the fact that CAR holds the record for peace processes as described throughout this analysis. The Bangui Agreement of 2019 revised could be a great success because of the United Nations engagement with CAR in this peace process. Nevertheless, our study shows that the realization of one of the features whose recurring failure studied here is not enough to give success to a peace process. The satisfaction of their fullness is required, otherwise a failure will be possible.

\section{Conflicts of Interest}

The authors declare no conflicts of interest regarding the publication of this paper.

\section{References}

American Friends Service Committee (2011). Transitional Justice Mechanisms, Lessons Learned from the Truth and Reconciliation Commissions. In International Conference on Transitional Justice Mechanisms (p. 1). Bujumbura: American Friends Service Committee.

Amnesty International (2011). Central African Republic: Time for Accountability. London: Amnesty International.

Bryden, A. (2007). Link between DDR and SSR 2. In Second International Conference on 
DDR and Stability (pp. 6-7). Kinshasa: United Nations Office of the Special Adviser on Africa (OSAA).

Chauvin, E. (2018). The War in the Central African Republic in the Shadow of Chad. A Regional Conflict Escalation? Paris: AFD.

Doui-Wawaye, A. J. (2012). Security, the Foundation of the Central African State: Contribution to the Research of the Rule of Law. Thesis, Bourgogne: University of Bourgogne.

Fernandez-Fernandez, E. et al. (2014). Definitions of Natural Resources and Implications for the Legal Process. Thinking of a Food Democracy, 2, 71-77.

FIDH (2008). Central African Republic, Déjà-vu, Peace (Dis)agreements That Are Detrimental to Victims ( ${ }^{\circ}$ 513a). Paris: FIDH.

France 24 (2013). Séléka Contests Its Place in the New Central African Government. https://www.france24.com/fr/20130204-seleka-conteste-place-gouvernement-centrafric ain-bozize-daffhane

Gerold, G., \& Merino, M. (2014). The Collapse of the Central African State in the Last Decade: Origins of the Crisis and Some Ideas for Getting out of It (No. 8). Paris: Foundation for Strategic Research.

International Crisis Group (2007). Central African Republic: Anatomy of a Phantom State. Africa Report, No. 136, Brussels: International Crisis Group.

International Crisis Group (2017). Avoiding the Worst in Central African Republic. Africa Report, No. 253, Brussels: International Crisis Group.

Karl, T. L. (1997). The Paradox of Plenty: Oil Booms and Petro-States. In Carbonnier, G. (Ed.), Comment conjurer la malédiction des ressources naturelles? Annuaire Suisse de Politique de Développement (pp. 84-85). Geneva: The Graduate Institute.

Loada, A. (2010). Part 14: Controlling Opposition in a Semi-Authoritarian Regime: The Case of Burkina Faso by Blaise Compaoré. In M. Hilgers (Ed.), Revolts and Oppositions in a Semi-Authoritarian Regime: The Case of Burkina Faso (p. 269). Paris: Karthala Editions.

Lombard, L. (2012). Rebellion and Limitations of Peace-Building in the Central African Republic. African Politics, 1, 189-208.

Mambo, P. (2012). The Relationship between the Constitution and Political Agreements in African States: Reflection on Constitutional Legality in Times of Crisis. McGill LaW Journal, 57, 921-952. https://doi.org/10.7202/1013034ar

Marchal, R. (2015). First Lessons of a "Funny" Transition in the Central African Republic. African Policy, 139, 123-146.

Marchal, R. (2016). Short History of a Singular Transition. Bangui: ROSCA G-D.

Mayneri, A. C. (2014). Central African Republic, from Seleka Rebellion to Anti-Balaka Groups (2012-2014): Uses of Violence, Persecution Scheme and Media Treatment of Conflict. African Politics, 2, 179-193. https://doi.org/10.3917/polaf.134.0179

Moloma, G. B. (2018). Central African Republic: When the Majority of Parliamentarians Initiate the Procedure of Impeachment of President Meckassoua from the Perch. Bangui City: CNC.

Mottet, C., \& Pout, C. (2011). Transitional Justice: A Path to Reconciliation and Building a Lasting Peace, Dealing with the Past-Series. In Conference on Transitional Justice (pp. 16-17). Yaoundé: Imprimerie Saint-Paul.

Ngoulou, F. (2019). Inclusive Government, Different from Inclusive Governance. Bangui City: Medias Centrafrique. 
Oscar, L. (2001). The Central African Crisis of Summer 2001. African Policy, 4, 163-175. https://doi.org/10.3917/polaf.084.0163

Philippe, H. (2003). Ivory Coast: Several Readings for an Announced Crisis. Contemporary Africa, 2, 105-127.

Reuter, O. J., \& Szakonyi, D. (2019). Elite Defection under Autocracy: Evidence from Russia. American Political Science Review, 113, 552-568. https://doi.org/10.1017/S0003055419000030

RFI (2019). RCA: The Resignations Are Linked within the New Government. http://www.rfi.fr/afrique/20190305-rca-demissions-s-enchainent-new-government-kha rtoum-accord

Specht, I. (2010). Socio-Economic Study in Ouham-Pendé, Ouham, Nana-Gribizi and Vakaga in the Central African Republic. Synthesis Report, Transition International, New York: UNDP.

The Sentry (2018). War Profiteering in the Central African Republic and the Bloody Rise of Abdoulaye Hissène, Washington DC: The Sentry.

UNHCR (2005). Country Profile: Central African Republic. New York: UNHCR.

UNHCR (2018). CAR Displacement Reaches Unprecedented Levels in 2017. New York: UNHCR.

United Nations (1997). Resolution 1125.

United Nations (1997). The Situation in the Central African Republic, Initial Deliberations, (3808th Meeting). New York: United Nations.

United Nations (2004). The Rule of Law and Transitional Justice in Conflict and Post-Conflict Societies: Report of the Secretary-General, S/2004/616. New York: United Nations.

United Nations (2014). Transitional Justice and Economic, Social and Cultural Rights. New York: United Nations.

United Nations (2017). Central African Republic 2003-2015, Report of the Mapping. New York: United Nations.

Yacine Toure, B. (1983). Africa: The Test of Independence. Genève: Graduate Institute Publications.

Yamamoto, H. (2007). The Tools of Parliamentary Control. Genève: Inter-Parliamentary Union.

Yves-André, F., \& Jean-François, M. (1995). The Business-State and the Entrepreneur Politicians Neo-Patrimonialism and Big Men: Economy and Politics (pp. 289-309). 